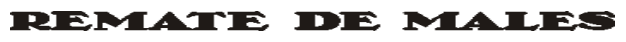

Campinas-SP, v.41, n.2, pp. 405-426, jul./dez. 2021

\title{
A PREdicaÇão de Cardozo nos VERSOS DE CABRAL
}

\section{The Predicament of Cardozo in Cabral's Verses}

\author{
Everton Barbosa Correia ${ }^{1}$
}

Resumo: Sendo Joaquim Cardozo o interlocutor mais recorrente ao longo da obra de João Cabral de Melo Neto, é possível visualizar uma série literária entre os poemas que celebram tal diálogo poético. Todavia, a interlocução permite que o conjunto de composições delineado aí se desdobre em dois níveis: o dos poemas em que o homenageado aparece no título do texto e aqueles outros nos quais sua ocorrência é acidental, adquirindo função predicativa, ora adjetival ora adverbial. Tal predicação será ilustrada retrospectivamente por meio de um adjetivo constante no livro A escola das facas (1980) e de um advérbio presente em Quaderna (1960), ambos inscritos sob o mesmo significante: "Cardozo". Considerada como uma dobra da convenção literária, interessa assinalar materialmente como tal influência foi se consolidando, no contexto editorial e no curso dos versos, a ponto de instituir um vinco na tradição poética brasileira.

Palavras-chave: Poesia Brasileira Moderna; Joaquim Cardozo; João Cabral de Melo Neto.

Abstract: Being Joaquim Cardozo the most recurrent interlocutor throughout the work of João Cabral de Melo Neto, it is possible to realize a literary series among the poems that celebrate such poetic dialogue. However, the dialogue allows the set of compositions outlined there to unfold on two levels: the poems in which the honoree appears in the title of the text and those others in which their occurrence is accidental, acquiring a predicative function, sometimes adjectival sometimes adverbial. Such predicament will be illustrated retrospectively by means of an adjective contained in the book A escola das facas (1980) and an adverb present in Quaderna (1960), both inscribed under the same signifier: "Cardozo". Considered as a fold of the literary convention, it is interesting to point out

${ }^{1}$ Departamento de Teoria Literária, Literatura Comparada e Literatura Brasileira (CULT), Universidade do Estado do Rio de Janeiro (UERJ): <evertonbcorreia@gmail.com>. 
materially how this influence was consolidating, in the editorial context and in the course of the verses, to the point of establishing a crease in the Brazilian poetic tradition.

Keywords: Modern Brazilian Poetry; Joaquim Cardozo; João Cabral de Melo Neto.

É sempre muito sedutora a hipótese de encontrar no mercado editorial brasileiro um nicho confiável para a aquisição de bens de consumo compatíveis com o seu anúncio. Contudo, não seria estranho encontrar alguém que se surpreendesse diante da aquisição de "obras completas" que fossem de fato incompletas, com coleção de poemas que se emendam inexplicavelmente a cada reedição e com edições críticas faltosas ou até mesmo inexistentes. Diante do quadro, a frequentação de uma obra se torna tão variável quantos forem os interesses a seu redor, sem considerar a possibilidade de dispor do texto como portador de uma unidade, ainda que cambiante, quando imantado pela fixação que o define. A exemplaridade textual se torna, por conseguinte, tão rarefeita quanto a mobilidade do escopo de leitura, que nunca poderá se postar num ponto fixo, como se a perspectiva não fosse um imperativo de cidadania nem de civilização. Em vez disso, a indefinição do objeto textual para a leitura se oferece como única possibilidade de identificação do leitor que, por seu turno, também se pulveriza, diluindo-se numa massa etérea, quase lúcida, porque supostamente sofrível e remediável. Em meio à dispersão geral, quem tiver a obsessão de se pautar por um mesmo assunto jamais terá água para jogar no moinho mercadológico, que passa a se mover por outras condicionantes estranhas à leitura do texto propriamente. Tudo isso será aguçado se o que estiver em pauta for algo tão indefinível ou tão incompatível com a turbidez daquela água quanto a figura de Joaquim Cardozo, que, à guisa de ilustração, sofrerá as mais variadas explorações no horizonte que a obra de João Cabral de Melo Neto nos dispõe.

A obra de João Cabral de Melo Neto disponibilizada em sua extensão editorial reúne a coleção dos seis poemas devotados a Joaquim Cardozo, que pode ser observada retrospectivamente sob a seguinte ordenação: 1. "Cenas da vida de Joaquim Cardozo", com 128 versos coligidos em dísticos no livro Crime na Calle Relator, após a edição da Nova Aguilar (1994), embora já aparecesse em quadras desde quando o volume foi reeditado em 1988 sob o título de Museu de tudo e depois; 2. "Na morte de Joaquim Cardozo", com quatro dísticos, e 3. "Joaquim Cardozo na Europa", com quatro quadras, publicadas ambas as composições inicialmente no volume A escola das facas (1980), pela José Olympio, tal como se mantiveram até agora; 4. "A luz em Joaquim Cardozo", com três quadras, e 5. "Pergunta a 
Joaquim Cardozo", com seis versos numa única estrofe, coligidos no livro Museu de tudo (1975), também editados pela José Olympio e cujos versos ainda constam tal como foram publicados originalmente; 6. "A Joaquim Cardozo", em cinco quartetos, no livro O engenheiro (1945), com ligeiras modificações nos versos que foram publicados em Duas águas (1956) e que só se fixaram em fins da década seguinte, por meio dos dois volumes Antologia poética $(1965 ; 1969)$ e Poesias completas (1968).

O saldo indiscutível e indisfarçável da circunstancial antologia é de 190 versos. Dificilmente encontraremos outra interlocução poética com a mesma quantidade de versos, de um autor devotado a outro. Na literatura brasileira, talvez somente a quantidade de versos que Carlos Drummond de Andrade escreveu para Manuel Bandeira possa se comparar à cifra alcançada por João Cabral na intertextualidade praticada com Joaquim Cardozo. Independentemente de qual seja o veredito, o fato certo é que estamos diante de um caso de exceção, a considerar os sujeitos envolvidos, seja Joaquim Cardozo na condição de objeto de especulação, seja João Cabral como poeta que escreve dezenove dezenas de versos ao interlocutor mais frequentado na sua escritura. Em termos historiográficos, trata-se de uma aberração, esvaziada pela curiosidade indesperta, que se dispersa. Sem jamais ser considerado para o desenvolvimento da poesia praticada em língua portuguesa, o diálogo poético fica siderado no limbo da excentricidade dos dois autores implicados.

Sob o ponto de vista instrumental, há um dilema difícil de enfrentar, uma vez que a perspectiva comparativa tem se voltado cada vez mais e prioritariamente para o cotejo de disciplinas afins à literatura, do que para interlocuções poéticas, cuja incidência - escassa - precisa ser celebrada quando acontece, a exemplo do trabalho de Ricardo Souza de Carvalho, intitulado A Espanha de João Cabral e Murilo Mendes (2014). Tratando-se de uma interlocução direta e mútua entre dois poetas, nada nos isenta de encarar alguns problemas de base: as considerações sobre a técnica do verso; a matéria de composição que anima a escritura dos poemas; ou mesmo, a relação com outras linguagens - arquitetura e pintura. Tais questões, listadas assim, de chofre, criam um problema de análise a ser equacionado por qualquer leitor, o que vale tanto para Antonio Houaiss (1976) quanto para Marco Lucchesi (2010), os quais registrarama apreciação da obra de Joaquim Cardozo. Porém a interlocução ora assinalada não tem sido cogitada como um ponto de cristalização da poesia brasileira mais recente, bem como de sua sedimentação formal junto aos leitores. 
Como quer que seja, cumpre referir que, além daqueles 190 versos cabralinos dedicados a Joaquim Cardozo, há também outros três momentos em que o nome do engenheiro aparece - como adjetivo, como advérbio e como substantivo - propriamente na pena de João Cabral. Retrospectivamente falando, a primeira dessas ocorrências é no poema "Prosas da Maré na Jaqueira", coligido no livro A escola das facas (1980), no qual constam outros dois poemas devotados a Joaquim Cardozo, já mencionados antes. A separação entre os poemas do mesmo livro se deve ao fato de que, nos outros dois, Joaquim Cardozo aparecia expressamente no título, conferindo uma centralidade à sua persona ao longo das composições, enquanto agora ele vai aparecer tangencialmente, mas não de modo menos revelador, porque exerce a função predicativa do texto, embora esteja grafado como nome. Depois do poema de $A$ escola das facas, a ocorrência seguinte - de acordo com a apresentação retrospectiva - seria identificada no volume Quaderna (1960), em que figura outra longa composição, intitulada "Poema(s) da cabra", no trecho indicado como "O aço do osso", onde a palavra "Cardozo" exerce função adverbial.

Para dar continuidade a essa pequena série dentro da série maior de poemas cabralinos devotados ao engenheiro, ressalte-se a primeira ocorrência do nome completo e por extenso de Joaquim Cardozo, que aparece no trecho "Dos coelhos ao cais de Santa Rita", constante no livro O rio (1954) - publicado logo após a desconcertante edição de O cão sem plumas (1950) -, que traz a seguinte dedicatória: "A Joaquim Cardozo, poeta do Capibaribe". Antes disso, e pela primeira vez, só havia aquele enigmático poema "A Joaquim Cardozo", reunido inicialmente no livro $O$ engenheiro, ladeado pelo poema "A Carlos Drummond de Andrade", com a mesma quantidade de quadras e consequentemente de versos.

O conglomerado de informações interessa na medida em que refere, com nome e sobrenome, um objeto que sombreia toda a poesia cabralina desde seu primeiro momento de formulação - se tomarmos a década de 1950 como um núcleo particular, porque centraliza como dedicatória e referência poética a repercussão de Joaquim Cardozo nas décadas posteriores ou na anterior -, quando adquire densidade e ressonância ao longo daquela escritura, notadamente porque amplia sua função, deixando de nomear um sujeito social determinado, para qualificar a performance literária sob a predicação de outra subjetividade autoral. Mais ainda, aquela subjetividade autoral predicativa indica um modo de ler e de compreender a poesia cabralina nos termos de sua própria elaboração, 
ainda que sob outro recorte desdobrado do primeiro (orientado pelos títulos das composições) e também retrospectivo. Daí a prevalência da observação do longo poema "Prosas da Maré na Jaqueira" como primeiro ponto de parada, localizado no livro A escola das facas, no qual, como já dissemos, "Cardozo" é utilizado como adjetivo.

\section{“CARDOZO", ADJETIVO ADVERSO NO POEMA "PROSAS DA MARÉ NA JAQUEIRA”}

A escola das facas é um livro, cuja dedicatória está grafada crua e desnudadamente assim: "A meus irmãos". E carrega uma epígrafe bastante sugestiva, porque grafada em inglês, que reza o seguinte: "Rooted in one dear/ perpetual place", seguida pela assinatura de W. B. Yeats. Supondo que o lugar perpétuo esteja radicado dentro do Recife, o bairro da Jaqueira é nomeado pela propriedade onde estava sediada a residência do avô materno de João Cabral, a qual serve de fonte e de referência a uma quantidade considerável de seus poemas, desde o que narra a circunstância de seu nascimento até tempos imemoriais: "Autobiografia de um só dia", "A roda dos expostos", "A múmia", "Porto dos Cavalos" ou "Lembrança do Porto dos Cavalos", que atravessam a memória coletiva vazada na afetividade oriunda da esfera familiar do poeta cravada à beira do Capibaribe, inscrevendo uma experiência simbólica que se traduz em versos. Sob tal visada, por vários aspectos, o poema "Prosas da Maré na Jaqueira" é o ponto culminante de tal experiência gravada em poesia, inclusive porque é constituído de oito partes, numeradas arabicamente, com três quadras cada uma, totalizando 96 versos.

Em meio aos 96 versos que constituem a composição, decerto alguns merecem destaque, a exemplo do "Maré do Capibaribe", que inicia sempre a primeira quadra de cada uma das oito partes constitutivas, fazendo as vezes de estribilho e estruturando a composição, além de soar também como vocativo, a chamar a "Maré", a quem se dirige na segunda pessoa do singular e que é tratada, portanto, como alguém próximo, senão íntimo. A "Maré" referida é, por conseguinte, a que chega nas proximidades do sítio da Jaqueira, onde estava plantada a casa do avô do poeta, Virgínio Marques Carneiro Leão, que foi professor catedrático de direito e deputado, casado com Maria Olindina de Mello - também professora -, genitores de Carmem Carneiro Leão, mãe do poeta e a qual, depois de casada, adotou o sobrenome Cabral de Mello. Da linhagem imediata de João Cabral, fica evidenciada certa ilustração, potencializada em seu tetravô de outro ramo 
familiar, que é Antonio de Morais Silva, primeiro dicionarista da língua portuguesa, a quem o poeta dedicou a composição homônima, coligida no mesmo A escola das facas. Por ora, basta lembrar que a inscrição física do espaço residencial se limita geograficamente com o rio, que representa a cidade e se faz índice da experiência cotidiana e sensível do poeta, transformando-se, para ele, em objeto de conhecimento de si e de sua localização social, radicada na ancestralidade com a qual convivia à beira do Capibaribe, que se convertia em "Maré" no dialeto da família, tal como o poema informa.

A estrutura compositiva do poema em cada uma das oito partes, constituídas de três quadras, pode ser descrita assim: na primeira quadra, a "Maré" é invocada e definida por algum aspecto que a aproxima do autor, seja geográfico, estilístico ou de temperamento; na segunda quadra de cada uma das oito partes, há uma problematização da definição estendida na estrofe anterior, que acumula e amplia a significação sedimentada ao longo do poema; ao passo que a terceira quadra arremata de modo imprevisto o que havia sido contradito e contrafeito verbalmente na estrofe anterior, engatilhando um sentido que se desdobra na parte seguinte, em outras três quadras. Diante do quadro esboçado, é preciso pontuar que o aparecimento de "Cardozo" como adjetivo no quarto verso da segunda quadra da quinta parte é antecedido por 48 versos, conforme a disposição abaixo transcrita. Com isso, o aparecimento de Joaquim Cardozo no poema, tanto no contexto da quinta parte quanto no da estrofe - por estar grafado na segunda quadra -, está condicionado por certa designação da "Maré" construída ao longo das quatro partes anteriores - igualmente constituídas de três quadras - e da estrofe contígua e antecedente, à qual se opõe como uma antítese, segundo o padrão que a composição institui e aqui se verifica.

\section{5}

Maré do Capibaribe, mestre monótono e mudo que ensinaste ao antipoeta (além de à música ser surdo)?

Nada de métrica larga gilbertiana, de teu ritmo; nem lhe ensinaste a diç̧ão do verso Cardozo e liso, 
as teias de Carlos Pena,

o viés de Matheos de Lima.

(Para poeta do Recife

achaste faltar-lhe a língua)

(MELO NETO, 198o, p. 66).

Os parênteses que encerram a terceira quadra da quinta parte trazem um enunciado que incide sobre o autor e sobre todos os demais poetas de quantos o Recife tenha produzido, ilustrados pelos poucos nomeados no poema. Tal ilustração leva ao entendimento de que, para ser poeta do Recife, é preciso ter a língua afiada ou, na verve, um valor inquestionável, mas não realizado a contento pela autoria em pauta, autoria que se mira e se espelha como uma sombra dos demais, aqui representados por Carlos Pena e Matheos de Lima, cujos atributos são inatingíveis para o João Cabral que se autonomeia como antipoeta entre poetas, conforme a primeira quadra. Entre os poetas, há a menção a Cardozo, logo após a qualificação de "gilbertiana" à métrica larga da Maré, contradita pela oposição da negativa "nem" à dicção "do verso Cardozo e liso". Embora antes o autor tivesse anunciado a Maré como "mestre monótono e mudo", ele parece agora duvidar da capacidade dela de lhe ensinar algo mais do que à música ser surdo. Então, cria-se a seguinte cadeia significativa: o antipoeta é surdo à música, não possui a métrica larga gilbertiana e tampouco o verso Cardozo e liso - todos os grifos para esta modalidade de verso que vem depois da métrica larga e gilbertiana.

Ora, pela enumeração de poetas, entre os quais Gilberto Freyre figura como portador de um ritmo próprio e largo, aprendido da Maré do Capibaribe - sendo a mãe de Gilberto Freyre irmã de Maria Olindina de Mello, avó materna do poeta -,percebe-se que muito provavelmente João Cabral também apreciava aquelas paragens do rio, ao qual se sobrepõe a dicção do "verso Cardozo e liso", que o poeta alega não ter aprendido. Curioso mesmo é que a qualificação desse verso, sendo Cardozo e liso, reproduz um procedimento tipicamente cardoziano, qual seja, o de enumerar uma quantidade de atributos para um mesmo substantivo, que absorve porosamente suas atribuições, sobretudo porque, entre os qualificativos, algum substantivo fará as vezes de adjetivo. O substantivo da vez que funciona como adjetivo é "Cardozo".

E aqui temos um dilema sobreposto e sobredeterminado: o verso é Cardozo e liso, porque sendo Cardozo é liso? Ou o verso é Cardozo e liso, porque, sendo Cardozo, se opõe a liso? Por outra, o verso liso seria 
uma extensão e, desde antes, uma característica do verso cardoziano? Ou ainda, o verso cardoziano iria se realizar por meio da oscilação entre ser espinhoso e liso? Conforme seja, João Cabral nesse momento do poema afirma não dispor de tal habilidade ou propriedade. A contradição das contradições é que tal afirmação no plano referencial vem acompanhada da realização de um verso que acumula e reproduz os procedimentos poéticos tipicamente cardozianos, quer consideremos a enumeração adjetival ou a substantivação dos adjetivos ou a adjetivação dos substantivos.

Dizendo que não aprendeu aquela modalidade de verso, como quer que o entendamos, realiza-o em todas as suas múltiplas possibilidades de entendimento. Tal contradição, paradoxal e paroxística, é de longo alcance e tem longa duração na obra de João Cabral, que já abusara do mesmo procedimento, ao menos, desde o ano de 1956, quando publicara suas Duas águas, com toda sorte de experimentação, inclusive a de Morte e vida Severina - que já traz no título o nome próprio "Severina" como qualificativo dos substantivos abstratos "morte" e "vida", para lhes conferir a materialidade incorrigível impregnada pela função adjetival de "Severina”. Algo como trinta anos depois daquela exploração da linguagem, aqui nesse poema, obviamente que o procedimento já foi assimilado de tal modo ao repertório cabralino, que não tem mais como deixar de ser seu, mesmo quando explicitamente caudatário do verso cardoziano, porque ganha autonomia. Por isso mesmo, o verso de João Cabral é e não é um verso Cardozo, porquanto, mesmo sendo realizado como tal, já está ele desvinculado da referência, pela localização remota do engenheiro que pertence ao eixo basilar da tradição poética brasileira moderna e pelo vasto uso que João Cabral vinha fazendo de tais procedimentos, muito proveitosamente. Ademais, na medida exata em que reproduz o procedimento, tal verso dilacera uma cisão entre sua materialização sonora, gráfica ou lexical e sua enunciação, que contradiz sua própria constituição de objeto estético, como se o verso pudesse ser somente uma coisa de dizer, e não de fruir nem de ensinar.

Para não descartarmos, de antemão, nenhuma das alternativas, passemos à análise do verso a partir da hipótese remota e, ainda assim, válida de que ele pode nos ensinar algo sob o verniz de um gosto acumulado ao longo da tradição poética e que, ocasionalmente, tem alguma graça.

A extensão "do verso Cardozo e liso" se constitui sintaticamente no espaço da página por uma quebra de sentido que nos remete de pronto ao verso anterior, cuja predicação se encerra ali. Ou seja, o cavalgamento de 
sentido que o constitui se dá pela qualificação da “dicção", grafada no verso anterior, que supostamente o autor não possui. Sem possuí-la no nível do enunciado, realiza o verso que materializa no espaço da página a dicção reivindicada, porquanto crispa a frase e encrespa a sonoridade do verso. Quer dizer, a menção a Cardozo no nível referencial faz-se, de fato, uma referência à sua exploração sonora e sintática, realizada no curso do verso, conforme assinalado. Pois a assonância formalizada pela contração da preposição "de" e a vogal "o" no início do verso se faz condicionante de uma leitura reiterativa, porque se repete na vogal tônica do nome "Cardozo", talvez com outra disposição sonora para a vogal: se a considerarmos antes como semivogal e depois como vogal fechada. Acompanhando a linha sonora do verso: aquele som vocálico de /u/ no início dele se abre em /e/, seguido pela repetição do /u/, para novamente se abrir, agora em /a/ e, logo em seguida, se fechar em /ô/, depois do que se planifica em tons de semivogais que finalizam o verso em /u/ e /i/. Figurando o movimento de uma linha para ilustrar a sonoridade das assonâncias, partiríamos de uma base na semivogal /u/, para abrir um arco pelo movimento das vogais abertas que irrompem e que, depois do fechamento do /ô/, se alternam em semivogais, simulando a figura geométrica de uma parábola.

Se quisermos a mesma linearidade do verso, repercutida sob a bitola da aliteração, disporemos da dental oclusiva disparando o verso, que se repete no nome "Cardozo", contraposto ao anterior som labiodental do /v/ que desvia o seu sentido, para se abrir na vibrante, que também ecoa o "verso" em "Cardozo". Curioso mesmo é que a sibilante de "verso" se sonorize em "Cardozo" e se mantenha sonorizada em "liso". Dito de outro modo, a oclusiva inicial repercute no nome do poeta citado, bem como a abertura vibrante em ambos os casos, sob o influxo da labiodental desviante, cujas repercussões se estabilizam por meio da sibilante que se sonoriza e finaliza o verso. A imagem da linha como figuração do movimento aliterativo é muito similar ao esboçado pelo movimento das assonâncias, só que com uma estabilização maior ao final do verso, porque as semivogais descritas antes se alternavam entre si, e agora a sibilante vai se sonorizar mais impositivamente. A ilustração da linha daí resultante é também a de uma curva que simula uma parábola, sobreposta à primeira (ilustrativa da assonância), e com a qual se identifica e se ajusta, reiterando a iteração anterior. Para finalizar a leitura sonora daquele verso, não há como fugir da cristalização fônica instaurada pela rima toante entre a palavra "ritmo" e "liso", com a mediação da palavra "dicção", que projeta 
na vertical outra linha sonora pautada pela semivogal. De uma maneira ou de outra, todos os possíveis acidentes do verso, quer entendamo- -los como uma linha isolada na horizontal ou na vertical, ou, ainda, como recorrência interna ao longo da estrofe - que é parte de um poema maior -, tudo aí concorre para a associação entre o desempenho linguístico em vários estratos da linguagem e a figura solar de Joaquim Cardozo, como uma referência autoral.

Diante da hipótese, parece-me lícito considerar o verso em pauta por meio de uma figuração sobreposta em duas bases sonoras - a assonância e a aliteração -, a forjarem uma crise que logo se estabiliza, seja em sibilante ou em semivogal, horizontal ou verticalmente. Pois o sentido conferido pelo cavalgamento desencadeado na palavra "dicção" institui o mesmo movimento, no nível sintático, de sobreposição formal que logo se estabiliza, o que também pode ser visualizado pela cadeia semântica estabelecida entre "ritmo" e "liso", sob a mediação de "dicção", que dilacera o ritmo deslocado para a átona, a qual logo se alisa. A cogitação é de afirmar se a dicção que dilacera o ritmo é de Joaquim Cardozo ou do próprio João Cabral. Mais ainda, se é deste sob o eco reverberado daquele. Talvez a adjetivação do substantivo "Cardozo" sirva para responder ao caso no estrato lexical, principalmente quando sobreposto a outro adjetivo, já que tal procedimento foi utilizado à exaustão por Joaquim Cardozo desde a década de 1920 e se faz, por isso, caracteristicamente cardoziano.

Também sob o ponto de vista rítmico, a redondilha solicita somente dois acentos: um na sétima e outro em qualquer sílaba. Ocorre que o verso analisado tem um acento a mais e, a princípio, desnecessário à redondilha, já que seu ritmo se constitui de três hemistíquios, o que se aplica também aos versos seguintes, em que aparecem Carlos Pena e Matheos de Lima. Aliás, nos três casos, o ritmo redondilho é o mesmo, com acentos na segunda, na quinta e na sétima sílabas, até porque, no caso do verso dedicado a Cardozo, não dá para contornar a palavra "verso", bem como não dá para contornar a palavra "teias" no verso a Carlos Pena nem a palavra "viés" no verso a Matheos de Lima. De igual modo, não dá para contornar o prenome dos dois poetas da terceira estrofe, nem o sobrenome de Joaquim Cardozo com "z", que é sempre algo mais do que espinhoso.

\section{CARDOZO, UM JEITO DE EXISTIR NOS "POEMA(S) DA CABRA"}

Aceito o argumento crítico de que a produção literária ulterior ilumina a prévia postura do autor, no que respeita tanto à sua persona pública 
quanto a seu traçado composicional, a hipótese interessa porquanto permite visualizar na trajetória de uma obra certo perfil estilístico em perspectiva, a serem abordados ambos os aspectos conjuntamente segundo os critérios que podem ser depurados da própria obra, em sua dimensão editorial ou na dos conceitos que lhe são decorrentes. Só não podemos esquecer que o exercício crítico, a pretexto de fazer um recorte de leitura, pauta-se por fazer eleições que são necessariamente exclusivas a partes da obra apreciada ou de objetos que lhe parecem obscuros, distantes de compreensão, o que no caso de João Cabral pode se aplicar a Vicente Yañez Pinzón - a quem o poeta devotou dois poemas - e, de um modo caricatural, a Joaquim Cardozo - a quem o poeta devotou as composições que estamos apreciando aqui, levando em conta a regularidade, a diversidade e a intensidade de seu comparecimento em tal obra como um objeto frequente e de frequência inusitada, porquanto não tem sido observada.

Pois, se é recorrente o aparecimento de Joaquim Cardozo na obra de João Cabral, pela longa duração, que ali permanece, dá margem à consideração de várias séries literárias, tanto na condição de objeto composicional, quanto pela cadeia de associações que enceta, o que vale para Frei Caneca e Vicente Yañez Pinzón - se tomarmos figuras históricas de relevo com as quais o engenheiro se limita, a exemplo do último verso do poema "Cenas da vida de Joaquim Cardozo": "Deu-nos um novo Frei Caneca” (MELO NETO, 2008, p. 594). No caso de Joaquim Cardozo, o limite de uma figura decalcada da realidade é ultrapassado em muito, porque ilustra, contribui e interfere nos princípios e no rendimento composicionais de João Cabral, os quais exigem demonstração, para não que percamos o fio da meada.

Seguindo a esteira metodológica em movimento, por estarmos cuidando exclusivamente da menção predicativa a Joaquim Cardozo na obra cabralina, a apreciação literária na ordem cronológica invertida teria como o próximo ponto de parada o livro Quaderna (1960), publicado primeiro em Portugal. Entre suas pérolas, ali figura o "Poema(s) da cabra" e que, por ser um ponto de inflexão na trajetória autoral, deter-nos-emos exclusivamente no "Poema da cabra" em que Joaquim Cardozoaparece. Não sem fazer antes alguma consideração editorial, sem a qual a compreensão do poema e sua consequente análise ficariam comprometidas, senão prejudicadas. 
A data de publicação de Quaderna adquire especial ressonância no contexto da interlocução autoral, porque, no mesmo ano de 196o e pela editora Livros de Portugal do Rio de Janeiro, Joaquim Cardozo publicara Signo estrelado, com seu retrato no frontispício, desenhado por Emiliano Di Cavalcanti. A coincidência editorial entre o Portugal de lá, que animou a publicação cabralina, e o daqui, que mediou a estampa cardoziana, é reveladora de um lapso histórico mais agudo, que passa pela consagração de ambos os poetas em proporções distintas. Pois, após a publicação de Duas águas (1956), João Cabral se fizera um poeta efetivamente nacional, a considerar a tiragem de milhares de exemplares numa época em que a população brasileira era pouco mais de cinquenta milhões, com uma significativa massa de analfabetos, o que dimensiona o alcance de sua circulação em meio ao público letrado.

A partir de então, esse jogo de espelhamento pareceu mais nítido, diferentemente de 1945, quando $O$ engenheiro veio a lume e, ainda que nele Joaquim Cardozo figurasse ao lado de Drummond na ordem de exposição dos poemas dedicados a um e a outro, a figura do engenheiro passou batida, a despeito de a composição "A Joaquim Cardozo" ter sido objeto da mesma quantidade de estrofes e exatamente na mesma disposição dos versos dedicada ao poeta mineiro naquela brochura. Como na ocasião Drummond já estava inscrito na historiografia, embaçava o entendimento de Joaquim Cardozo, pela falta de simetria editorial, porque este autor ainda era inédito em livro e ali ficou como um forte candidato ao esquecimento, como contraparte necessária da falta de adequação sua aos grupos literários e de estratégias de projeção cultural vigentes.

A despeito de tudo isso, João Cabral se manteve invencível no delineamento da figura do engenheiro, a exemplo de como é talhada nessa sua primeira composição a este devotada, sob a marca de ser o seu interlocutor dileto pela contabilidade que se descola das respectivas publicações da Nova Aguilar, na qual ambos já foram publicados em capa dura e papel-bíblia. Mesmo assim, é necessário pontuar as distinções entre os tratamentos dispensados aos respectivos poetas, seja pela diferença de tiragem dos seus volumes ou do acabamento editorial.

O rosário de informações interessa para dimensionar a recepção daquela obra no contexto de sua publicação e como o autor já aparecia naquele momento para seu público, mesmo antes de entrar na Academia Brasileira de Letras (ABL) e de se tornar cônsul ou embaixador. O seu lugar social e literário não era ainda o que veio a se consagrar posteriormente, 
mas já era digno de apreço e de afeto entre os seus leitores. Não há indicação precisa sobre a circulação do volume original em Portugal ou no Brasil, mas sabe-se que a publicação a lhe dar maior visibilidade ainda foi Terceira feira (1961). Esta foi a publicação a que ficou associado o livro Quaderna, para os leitores de poesia no Brasil, até porque teve tiragem acima da média dos livros de poemas, a considerar a quantidade de exemplares que ainda hoje podem ser encontrados em sebos, e, como era praxe numerar os livros na época, a numeração constante nesses livros sempre ultrapassa a cifra de dois mil. Não bastasse o êxito editorial por si, o livro se gravou na memória nacional devido à quantidade de poemas que podem ser tomados como ilustrativos da produção autoral, a exemplo de "Estudos para uma bailadora andaluza", "A palo seco", "Jogos frutais" e "Poema(s) da cabra”. Este último nos interessa mais imediata e incisivamente, porque traz uma ocorrência algo entre inusitada e curiosa do sobrenome "Cardozo", que por óbvio remete à figura do engenheiro e poeta dileto do amigo autor.

Ainda que suas quadras estivessem sendo gestadas desde antes, de Quaderna em diante é possível dizer que se estabelece na produção de João Cabral o império do quatro, em quantidade de sílabas poéticas, de versos e de estrofes, necessariamente mediadas e cindidas pelo quatro, quando não pela quadra propriamente, que passa a animar seu desempenho autoral, o que já vinha se delineando nesse sentido, ao menos, desde Duas águas (1956), mas que agora ganhava recurso e sistema. No livro Quaderna mesmo só há espaço para o que couber na quadratura do quatro, com quadras em grupos de quatro e não será diferente com os "Poema(s) da cabra".

Constituída de onze grupos de quatro quadras, a composição dispõe de quarenta e quatro quadras, que podem ser lidas como partes de um todo ou, ainda, como grupos isolados e autônomos de quatro quadras, que se multiplicam entre si, conforme está sugerido pelo título "Poema(s) da cabra”, podendo ser simultaneamente um só poema e vários. Sem desconsiderar a hipótese de leitura da totalidade das onze partes, a leitura aqui desenvolvida tende a privilegiar a unidade autônoma do grupo de quatro quadras como um poema em que aparece o sobrenome do engenheiro-poeta, a pretexto de dar maior nitidez à visualização da intertextualidade metalinguística entre Joaquim Cardozo e João Cabral. Mesmo que a significação construída ali seja decorrente do que havia sido dito antes, quer consideremos o contexto do poema quer consideremos o 
desenvolvimento da obra, o foco será a particularidade significativa que se desenrola no curso daquelas quatro quadras. Óbvio está que, assim, a autonomia do poema vem a ser relativizada, porque efetivamente se trata de uma composição de autonomização condicionada ao todo de que é parte, ainda que a tomemos como sendo uma totalidade. Porque tal autonomia está delimitada, a ela se faz - e fará menção a isso - com o propósito justo e explícito de valorizar a significação que está em processo, e não engessada no texto. Assim, o poema aqui abordado comporta certa abertura, porquanto sua significação não está previamente dada, como se vê, no curso dos versos nem na parte do poema indicada como "O aço do osso”, se o tomarmos pela sua grafia no espaço da página, que varia de acordo com a edição.

\begin{tabular}{|c|c|}
\hline O núcleo da cabra é visível & ER 8 (2-5-8) O AÇO DO OSSO \\
\hline ixo do homem do Nordest & ER $8(4-8)$ \\
\hline Da cabra lhe vem o escarpado & ER $8(2-5-8)$ \\
\hline estofo nervudo que o e & ER $8(2-5-\varepsilon$ \\
\hline
\end{tabular}

Se adivinha o núcleo de cabra

ER 8 (3-5-8)

no jeito de existir, Cardozo,

ER $8(2-6-8)$

que reponta sob o seu gesto

ER $8(3-5-8)$

como esqueleto sob o corpo.

ER $8(4-8)$

E é outra ossatura, mais forte

ER $8(2-5-8)$

que o esqueleto comum, de todos; ER 8 (3-6-8)

debaixo do próprio esqueleto, ER $8(2-5-8)$

no fundo centro de seus ossos. ER 8 (4-8)

A cabra deu ao nordestino

ER $8(4-8)$

esse esqueleto mais de dentro

ER $8(4-8)$

o aço do osso, que resiste

ER $8(4-8)$

quando o osso perde seu cimento. ER 8 (4-8)

(MELO NETO, 196o, p. 91).

Uma exclusividade gráfica da primeira publicação de "Poema(s) da cabra” na edição princeps do livro Quaderna, que repercute no leitor, é a fixação de expressões ao lado direito da página, para indicar o andamento da leitura, bem ao gosto medieval e ibérico, que o autor já tinha utilizado anteriormente. Como, no caso dos "Poema(s) da cabra", a indicação nuclear 
de cada poema era retirada da própria composição, nas edições seguintes elas passaram a constar somente no interior do texto, em itálico, tal como acontece com "o aço do osso" em todas as edições subsequentes. Acontece que, como é bem sabido, o itálico atualmente se faz uma marca gráfica, que serve para indicar estrangeirismos e periódicos, e, quando aplicado a palavras exclusivas no "Poema(s) da cabra", cria uma ambiguidade, como se o poeta estivesse referindo algum jornal ou expressão particular do contexto recifense ou sevilhano, o que não é o caso das palavras todas grafadas em itálico ao longo da extraordinária composição.

Como se trata de um texto extenso - constituído de onze partes -, que inclusive pode ser lido autonomamente parte por parte, nada mais oportuno do que marcar cada uma delas com um distintivo, que, no caso em foco, pode ser o sintagma: "o aço do osso", alçado à condição de paradigma quando ladeado ao texto, reforçando o sentido poético, conforme consta na edição original. Em vez disso, ao simplesmente ser indicado pelo itálico no interior do próprio texto, além de deixar atenuado o poder comunicativo daquela expressão, o distintivo tem seu sentido suprimido como núcleo composicional, ao passo que dá margem a ambiguidades pela indicação gráfica em itálico, que não precisa nem especifica o motivo de tal distinção no curso do verso nem da frase. Com isso, aquela hipotética potencialização de sentido dada pelo destaque do "sintagma" ao lado do texto, quando alçada à condição de núcleo ordenador do poema, marca ali uma significação específica. De outro modo, quando a expressão destacada é internalizada em itálico, adquire a feição de um enigma quase indecifrável, porque não oferece recursos para que se entenda a sua distinção naquele momento específico de comunicação poética. Portanto, há um efeito de leitura exclusivo da composição, que só está acessível a quem dispuser da coleção original, posto que fosse diluído ou esfumado em todas as edições seguintes.

Acontece que esse diferencial de leitura pareceu dispensável, na medida em que as indicações marginais ao texto já constavam no próprio corpo da composição, de onde haviam sido retiradas para figurar na primeira edição do livro. À proporção que voltaram para o lugar original do texto nas edições posteriores, exclusivamente sob a indicação de itálico que se contrapõe à originalidade gráfica daquela encadernação, tornam o texto invariavelmente ambíguo. O autor, que já havia feito uso de tal procedimento antes em "Antiode" (1947), O cão sem plumas (1950) e $O$ rio (1954), talvez quisesse que tal procedimento fosse lido como um 
traço distintivo seu. Ademais, torna-se muito difícil acompanhar o desenvolvimento de uma longa composição à revelia da paginação ou de um enredo intrincado - comoé o caso. Por outra, soa enigmático a qualquer leitor aludir a uma significação exclusiva para a grafia das palavras em itálico, que constituem vários sintagmas ao longo da extensa composição que é "Poema(s) da cabra", a exemplo de "mais barato", "negro de vida", "apenas côdea”, "inconformado, inconformista”, "parte com o Diabo", "capaz de pedra”, "jamais contemplativa”, "mesma casta” e "o aço do osso". Nos nove "Poema(s) da cabra", numerados depois da edição princeps, não há relação nenhuma entre os sintagmas destacados ali em itálico, a não ser pela função que exercem particularmente em cada composição.

A distinção em itálico só obscurece o sentido em curso, até porque há dois poemas, cujos sintagmas nucleares não foram margeados ao texto como paradigmas, nomeadamente o primeiro e o último dos onze "Poema(s) da cabra", que, além do mais, estão entre parênteses, segundo a grafia que se lhe consigna a posteriori. Logo, sem as referências gráficas da primeira edição, fica impossível ao leitor saber porque alguns dos "Poema(s) da cabra" possuem sintagmas em itálico e outros não, sobretudo se já não havia motivo antes para aquela grafia exclusiva vir em itálico. Diferentemente do que acontece quando da reprodução do sintagma ao lado do texto, pois que é especificado no próprio espaçamento da página a sua função nuclear no contexto de cada uma daquelas nove composições, que seguem uma cronologia também especificada pelas indicações gráficas. Considerados os poemas entre si, aquele a nos interessar mais de perto é o nomeado como "o aço do osso" na primeira edição e que, nas edições posteriores, traz este sintagma em itálico, e que tem repercussão das nove composições anteriores - as quais o preparam - e na posterior - que o sucede -, arrematando o extenso texto de 11 poemas, 44 quadras e 176 versos, dentro os quais nos deteremos nos dezesseis já transcritos acima.

Para efeito de leitura, tomando as quatro quadras indicadas como pertencentes ao poema "o aço do osso" isoladamente, é preciso fazer certa descrição lexical, haja vista que ali algumas palavras se repetem: "cabra" (4 vezes); “esqueleto" (4 vezes); “debaixo", "sob”, "é” e "osso" (2 vezes), com a variação de "ossos" no plural. Daí a primeira informação a ser depurada é que as preposições "debaixo" e "sob" são equivalentes no nível semântico e, por conseguinte, poderiam se enquadrar entre as palavras que são repetidas quatro vezes, ao passo que a palavra "osso" tem mais uma 
ocorrência no plural, multiplicando os ossos repetidos ou diversificando aquilo que singularizava o poema e que se abre em múltiplas significações ao seu final. O verbo "é", com duas ocorrências, aponta para o estado ou a condição de a cabra ser ou estar para algo. No mais, as outras ocorrências verbais são construções apassivadoras ou passivas mesmo, à exceção do verbo "dar", assim constante no verso: "a cabra deu ao nordestino", que engatilha a quarta quadra. Não deixa de ser curioso que a cabra dê alguma coisa que não seja carne, leite ou mesmo a pele. Em vez destes, o que ela dá é "o aço do osso", que identifica aquela composição ou aquele conjunto de quatro quadras o qual também compõe o poema, em demarcação recuada à direita no espaço da página ou em itálico no corpo do próprio texto, a depender da edição compulsada.

De todo modo, há uma associação semântica a ser feita do aço para o osso, do osso para o esqueleto e daí para o homem, que recebe o qualificativo de "nordestino", ilustrado pelo jeito de existir Cardozo, que é derivado do núcleo da cabra. Assentado deve ficar que tal operação lógica se desestabiliza no poema, uma vez que os termos estão dispostos noutra ordem, a saber: o núcleo da cabra é visível - portanto, existe - debaixo do homem do Nordeste, a quem é dado pela própria cabra o escarpado e o nervudo, do qual deriva um jeito de existir associado a Joaquim Cardozo, por sua vez, também visível nos seus gestos como o esqueleto no corpo, em cujo centro se faz mais forte o osso, porque ali reside o seu aço, cuja resistência é transferida ao nordestino, tendo sido esta herdada da cabra. Também, por reduplicação, a locução "da cabra” conduz ao adjetivo "cabral" que se substantivou e se sobrenominalizou, identificando o autor da composição.

Ainda no nível vocabular, a palavra "escarpado" é indicativa de uma formação geológica nucleada por pedras íngremes e também traz consigo anagramaticamente a palavra "cardo", que remete a espinho e ecoa a "cabra", sem deixar de se derivar em "Cardozo". Se "escarpado" ressoa em "Cardozo", este, por sua vez, rima toantemente com "corpo", donde se depreende uma associação semântica decorrente da sonoridade, que estabelece uma cadeia significativa entre o corpo do homem que Joaquim Cardozo encarna ou representa e que é escarpado. Cardozo é, afinal, um jeito de existir e exerce, portanto, função adverbial no contexto da composição, uma vez que sua predicação não é exclusivamente adjetival, mas se estende como um advérbio de residual duração ao longo do poema. Ou seja, à medida que a palavra "Cardozo" apositivamente se grava sobre 
o jeito de existir - e não somente sobre homem ou sobre o qualificativo imediato (nordestino) -, sua colocação no texto se faz mais remota e opaca, e menos atuante ou visível. Contraditoriamente, embora a palavra "Cardozo" pareça querer saltar no curso do verso e apareça escondida no curso do poema, ela se inscreve semanticamente num nível mais fundo, posto que qualifica adverbialmente certo jeito de existir, um modo de ser, que passa a núcleo de conduta: o aço do osso.

A sonoridade é tanto mais significativa quanto mais a concebemos inscrita no nível rítmico do octossílabo praticado no poema, com um equilíbrio cambiante entre as quartas e as quintas sílabas tônicas, como marcantes dos respectivos segundos hemistíquios - com sete incidências para cada um desses ritmos - e com duas ocorrências variáveis da tônica na sexta sílaba, notadamente nos versos 6 e 10, coincidentemente os segundos versos da segunda e da terceira estrofes, nos quais podemos entender que se radica o núcleo do poema, ilustrado pelos seguintes versos: "no jeito de existir, Cardozo," e "que o esqueleto, comum a todos". Esses dois versos adquirem uma associação semântica compulsiva, devido à amarração rítmica: são versos que não se bastam, porque são derivados de cavalgamentos, demandando expansão e extensão significativa. Com isso, a mesma especificidade rítmica que os contrapõe a outros versos se estende para a sintaxe, uma vez que o enunciado do verso, por si mesmo, não se esgota ali e ali se faz insuficiente à compreensão.

Na ordem disposta pelo poema, o verso "no jeito de existir, Cardozo," só tem seu enunciado expresso quando completado pelo verso que o antecede: "se adivinha o núcleo de cabra". Ora, se o núcleo de cabra está sinalizado pelo jeito cardoziano de existir, ou ainda, se é perceptível o núcleo de cabra numa existência cardozianamente descrita, só significa que há uma equivalência entre a universalização construída pela cabra - proposta no poema - e a particularização de que decorre a figura especular e espectral de Joaquim Cardozo, a qual sedimenta efetivamente no texto um jeito de existir. E a equivalência entre o núcleo de cabra e o jeito de existir Cardozo se desdobra em outras equivalências, enunciadas nos versos seguintes: "que reponta sob seu gesto/ como esqueleto sob o corpo". Quer dizer, o núcleo de cabra está para o jeito de existir Cardozo, assim como o esqueleto está para o corpo, o que pode ser percebido pelo seu gesto, no qual um ou outro desponta, seja o osso ou o núcleo de cabra, seu aço. Por conseguinte, o núcleo de cabra se faz ósseo, de outra ossatura mais forte que a material, sem deixar de sê-la, tal como está enunciado 
na estrofe seguinte, em que consta o outro verso com o ritmo 8 (3-6-8), idêntico ao verso Cardozo.

E é outra ossatura, mais forte que o esqueleto comum, de todos, debaixo do próprio esqueleto, no fundo centro de seus ossos.

Reside no segundo verso dessa estrofe tanto o ritmo que sugere oposição e complementaridade aos outros, quanto a complementaridade da função sintática similar ao verso Cardozo e a oposição ao restante dos versos que o explicam, por diferenciação. Parte da explicação já foi dada: o verso "que o esqueleto comum, de todos" constitui-se numa comparação anunciada no verso anterior, a qual revela ser o núcleo de cabra de uma ossatura mais forte que o esqueleto comum a todos. Cavalgando no sentido acumulado, o jeito de existir Cardozo - em que se radica o núcleo de cabra - constitui outra ossatura, mais forte que o próprio esqueleto, debaixo do qual aquela "infraossatura" se resguarda, "no fundo centro de seus ossos", onde supostamente estaria depositado "o aço do osso", que nomeia este "Poema da cabra" ou esta parte dos "Poema(s) da cabra", tal como está indicado à direita da página da edição princeps e em itálico nas edições subsequentes, que se lhe acumularam a partir da edição de Terceira feira (1961).

É preciso referir, ainda, que, assim como o verso Cardozo incita uma travessia rítmica e sintática para os versos que lhe são contíguos e destes para as estrofes próximas, seja a anterior ou as posteriores, tal movimento articulatório simula um tecido discursivo que não fica restrito a este "Poema da cabra" nem aos demais "Poema(s) da cabra", mas vem a ser indicativo de uma característica expressiva do autor, que se converte, por seu turno, em traço estilístico, para além do uso vocabular, embora parta justamente do horizonte dado pelo léxico. Outra possível ilustração do mesmo movimento lexical pode ser identificada no primeiro verso do "Poema da cabra" identificado como "o aço do osso", que reza o seguinte: "O núcleo da cabra é visível”. Este verso faz as vezes de refrão modalizado, dado que o primeiro verso do "Poema da cabra" anterior, sob a indicação de "mesma casta”, é o que se segue: "Um núcleo de cabra é visível”, diferindo do outro pelo artigo que antecede "núcleo", passando assim de indefinido para definido, e da preposição "de", que sofre contração e se grafa "da" no "aço do osso", reforçando a definição acerca de qual cabra se fala, não só a 
determinada pelo artigo que define o seu núcleo, mas também pelo que define a cabra mesma de que se fala.

Fazendo a oposição entre as duas variações do mesmo verso que se repete modalizado, faz-se também a oposição entre dois daqueles "Poemas da Cabra": "mesma casta", pautado pela versão indefinida do refrão; e "aço do osso", que nos disponibiliza sua versão definida como um ponto de chegada. Acontece que, se fizermos a leitura retrospectiva, a fim de acompanhar o percurso pelo qual se chegou até ali, vamos perceber que a modalização do verso inicial que se faz estruturante daquele "Poema da Cabra”, porquanto repercute o anterior, tem as seguintes variações nucleares dos oito anteriores "Poema(s) da Cabra", com que se limita e se identifica: 8. "Um núcleo de cabra é visível", 7. "A vida da cabra não deixa”, 6. "Não é pelo vício da pedra”, 5. "A cabra é o melhor instrumento", 4."Quem já encontrou uma cabra”, 3. "O negro da cabra é o negro", 2. "Se o negro quer dizer noturno", 1. "A cabra é negra. Mas seu negro”. Como já foi dito, além desses nove "Poema(s)s da Cabra", há o primeiro e o décimo primeiro, emoldurando-os entre parênteses. No primeiro, não há a ocorrência da palavra cabra e, no décimo primeiro, há o seguinte verso: "descrevendo-lhe as cabras negras", que nos remete ao único verso que se repete literalmente, letra por letra, ao longo daqueles poemas: "O negro da cabra é o negro". No poema 1, identificado como "mais barato", "cabra” forma o seguinte dístico: "O negro da cabra éo negro/ do preto, do pobre, do pouco". Enquanto no poema 3, assinalado como "apenas côdea”, constitui o seguinte dístico: "O negro da cabra é o negro/ da natureza dela cabra", o que dá a entender, por outras vias, um percurso que vai da materialidade das circunstâncias sociais, mais sensíveis e notórias, até sua nucleação na linguagem suportada pela cabra, cujo centro ou negro é ela própria, também traduzida em "Cardozo", em que é visível ou reside o núcleo da cabra. Há, portanto, uma constituição de sentido no texto, depurado das situações, animais, objetos, artistas e pessoas que se sedimentam e se consumam em Joaquim Cardozo, que serve de predicação para a elaboração poética de João Cabral, constituída em vários níveis: lexical, sonoro, rítmico, métrico, sintático e naturalmente semântico. Sendo Joaquim Cardozo o lugar propício onde se adensa o núcleo da cabra, não tem ele como deixar de ser visível como um núcleo da poesia de Cabral, ao menos nestes "Poema(s) de cabra". Se nem a argumentação nem a análise tiverem sido suficientes para a demonstração, fica a lembrança de que, naquele momento de afirmação da dicção cabralina, estes "Poema(s) da 
cabra” reuniram 44 quadras, distribuídas ao longo de 176 versos, os quais se constituíram como um significado que vale por si mesmo.

\section{REFERÊNCIAS}

CARDOZO, Joaquim. Signo estrelado. Rio de Janeiro: Livros de Portugal, 1960.

CARVALHO, Ricardo Souza de. A Espanha de João Cabral e Murilo Mendes. São Paulo: Editora 34, 2011.

HOUAISS, Antonio. Drummond, mais seis poetas e um problema. Rio de Janeiro: Imago, 1976.

LUCCHESE, Marco. A mais longa viagem. In: CARDOZO, Joaquim. Poesia completa e prosa. 2. ed. Rio de Janeiro: Nova Aguilar, 2010, pp. 131-147.

MELO NETO, João Cabral de. O engenheiro. Rio de Janeiro: Amigos da Poesia, 1945.

MELO NETO, João Cabral de. Antiode. In: Psicologia da composição. Barcelona: O Livro Inconsútil, 1947, [s.p.].

MELO NETO, João Cabral de. O cão sem plumas. Barcelona: O Livro Inconsútil, 1950.

MELO NETO, João Cabral de. O rio ou relação da viagem que faz o Capibaribe de sua nascente à cidade do Recife. São Paulo: Comissão do IV Centenário da Cidade de São Paulo, 1954 .

MELO NETO, João Cabral de. Duas águas. Rio de Janeiro: José Olympio, 1956.

MELO NETO, João Cabral de. Quaderna. Lisboa: Magalhães Editores, 1960.

MELO NETO, João Cabral de. Terceira feira. Rio de Janeiro: Editora do Autor, 1961.

MELO NETO, João Cabral de. Antologia poética. Rio de Janeiro: Editora do Autor, 1965.

MELO NETO, João Cabral de. A educação pela pedra. Rio de Janeiro: Editora do Autor, 1966.

MELO NETO, João Cabral de. Poesias completas: 1942-1965. Rio de Janeiro: Sabiá, 1968.

MELO NETO, João Cabral de. Antologia poética. Rio de Janeiro: Sabiá, 1969.

MELO NETO, João Cabral de. Museu de tudo. Rio de Janeiro: José Olympio, 1975.

MELO NETO, João Cabral de. A escola das facas. Rio de Janeiro: José Olympio, 198o.

MELO NETO, João Cabral de. Crime na Calle Relator. Rio de Janeiro: Nova Fronteira, 1987. 
MELO NETO, João Cabral de. Museu de tudo e depois: poesias completas II. Rio de Janeiro: Nova Fronteira, 1988.

MELO NETO, João Cabral de. Obra completa. Rio de Janeiro: Nova Aguilar, 1994.

MELO NETO, João Cabral de. Poesia completa e prosa. Rio de Janeiro: Nova Aguilar, 2008.

Recebido: 16/11/2020

Aceito: 22/6/2021

Publicado: 22/12/2021

Remate de Males, Campinas-SP, v.41, n.2, pp. 405-426, jul./dez. 2021 - 426 